\title{
The Motivating Drives behind Dreams and Nightmares in ancient Egypt According to Freud's Theory
}

\author{
Heba Maher Mahmoud Ahmed \\ Lecturer, Faculty of Arts, Mansoura University, Egypt \\ hebamaher@mans.edu.eg
}

\begin{abstract}
The ancient Egyptians put quite a bit of emphasis on dreams, although they had no verb for dreaming. It may suggest that they did not consider it an activity but rather a visual phenomenon, which was an uncontrollable phenomenon external to the dreamer. They linked sleep to death (and afterlife), felt that the messages delivered in their dreams could achieve the desire, cure an illness, give the power and help them in important decisions, such as where they build a temple to the point of when they wage war. It may be used as a window to see the dead and their activities. However, there were types of scary dreams, which bring Devils and evil spirits. As sometimes the result was a positive beneficial experience, as is attested in New Kingdom royal texts and elite hymns that relate, the awe-inspiring could have contacted a dreamer with a god or a goddess. There was another more disturbing belief that dreams could also allow the vulnerable sleeper to be watched or even assaulted by the hostile dead, while today we call these events 'nightmares' and consider them psychological phenomena. The cause of dreams was not ascribed to any particular demon, but rather to the generic hosts of hostile dead and other chaotic beings who had crossed over from the afterlife. According to Freud's theory, there were motivating drives behind all these types of dreams and nightmares, which is based on linking dreams to unconscious psychological life. It may be returned to one of the instinctive repressed desires, which stored in the subconscious, it makes its way during the sleep from the subconscious to the conscious, and it reveals itself as a dream. Or it may be a different desire from a waking life; some ideas that exist before conscious after it contains conflicting motives. It received support during sleeping from one of the emotional elements. So, the dreams may be emerging from the ego.
\end{abstract}

Keywords: $r s w . t, s \underline{d} r, k d d$, Dreams, Nightmares, Freud, stimuli, Guilt, Desire, illness, warning, Dream Incubation, Dream Book, divination, Spells, Headrests, cobra. 


\title{
الدوافع المحفزة للأحلام والكوابيس فى مصر القديمة وفقًا لنظرية فرويد
}

\author{
هبة ماهر محمود أحمد \\ مدرس، كلية الأداب، جامعة المنصورة، مصر
}

hebamaher@mans.edu.eg

الملخص: ركز المصريون القدماء على الأحلام شأنهم شأن العديد من النقافات القديمة، على الرغم من إنه لم يكن لديهم أي فعل للحلم. ربما يشير ذلك إلى أنهم لم يعتبروا ذلك نشاطًا، بل ظاهرة مرئية، لا يمكن السيطرة عليها. ولقد ربطوا بين النوم والموت (والحياة الآخرة)، وشعروا أن الرسائل المرسلة في أحلامهم يمكن أن تحقق رغبة، وتعالج مرض، وتمنح سلطة، بل وتساعدتهم على اتخاذ قرارات هامة إلى حد تحديد مكان بناء معبد جديد أو متى تُشن حرب. ويمكن أن تكون الأحلام بمثابة نافذة لروية أنشطة الموتى. ومع ذلك كانوا يخشون في كثير من الأحيان أنواع أخرى من الأحلام تُمَّى "الكوابيس"، يمكن أن نؤدي إلى ضرر أو إلى رؤية أرواح غير مرغوب فيها. ووفقًا لنظرية فرويد لتفسير الأحلام، كانت هنالك دوافع مُحفِة وراء كل أنواع الأحلام والكوابيس؛ حيث هناك علاقة بين الأحلام واللاوعي لدى الحالم؛ فربما سبيتها واحدة من الرغبات الغريزية المكبوتة بداخله، والمخزنة بالعقل الباطن والتي أخذت طريقها من اللاوعي إلى الوعي أثناء النوم، ثم كثفت عن نفسها في صورة حلم. أو ربما سبيتها رغبة مختلفة عن حياة اليقظة للحالم؛ حيث بعض الأفكار الموجودة قبل الوعي بعد أن تحتوي على بعض الدوافع المنضاربة والتي تلقي الدعم أنثاء النوم من أحد العناصر العاطفية. لذلك قد تنشأ الأحلام من الأنا.

الكلمات الدالة: rsw.t, sd dr, kdd، الأحلام، الكوابيس، فرويد، الثعور بالذنب، الرغبة، المرض، حضانة الأحلام،

$$
\text { كتاب الأحلام، العراف، التعويذات، مساند الرأس، الكوبرا. }
$$




\section{Introduction:}

The power of dreams as well as the function of Dreaming has played essential roles in many ancient cultures. Dreams were conceived as messages from the Gods in Ancient Egypt and Mesopotamia. ${ }^{1}$ Because of their unique standing outside the regular bounds of space and time, dreams have often been thought to contain hidden messages or secrets from the justified dead ' $3 h . w$ ', the unjustified dead ' $m w t . w$ ' and gods ' $n t r . w$ '. So, it needs interpretation in order to be understood properly' ${ }^{3}$ Metaphor of dreams is used in many Literacy texts such as 'the teachings of Ptahhotep' for emphasize that which is ephemeral, untrustworthy, and potentially dangerous. ${ }^{4}$ Also in 'The Teaching of King Amenemhet I' for his son 'Senwosret' given by 'Amenemhet I', after his assassination, to 'Senwosret', presumably in a dream or vision, although this is nowhere specifically stated. ${ }^{6}$ Furthermore in the tale of the 'Eloquent Peasant' for emphasis his speech ${ }^{7}$, he said: 'It is the eater who tastes, it is he who is questioned who answers, and it is the sleeper who sees the dream'.

In previous, the studies of dreams and nightmares in ancient Egypt usually focused on the political use of dreams and the interpretation of the dream book without studying the motivating drives behind Dreams and Nightmares, as well as the motivating behind its interpretations. So in this paper I will focus on these motivating drives, where the dream involves two main contents; visible content and hidden content. The ideas of dream and the dream content are presented like two sides of the same topic and the same matter in two different languages. Or, more properly, the dream content seems like a meaning of ideas of dream into another expression.

\footnotetext{
${ }^{1}$ Astrid Møller-Olsen, "Sharing a Dream: The Lucid Dreamscapes of Jorge Luis Borges and Can Xue," International Conference 'Exploring the China Dream' at Stockholm University (2015): 1.

${ }^{2}$ Kasia Szpakowska, "Nightmares in Ancient Egypt," in Le cauchemar dans 1'Antiquité: Actes des journées d'étude de l'UMR 7044 (15-16 Novembre 2007, Strasbourg), ed. Jean-Marie Husser and Alice Mouton (Paris: de Boccard, 2010), 23; Laura Dewsbury, "Invisible Religion in Ancient Egypt: A study into the individual religiosity of non-royal and non-elite ancient Egyptians" (PhD diss., University of Birmingham, 2016), 243-244; Kasia Szpakowska, Behind Closed Eyes: Dreams and Nightmares in Ancient Egypt (Swansea: The Classical Press of Wales, 2003), 123.

${ }^{3}$ Dewsbury, "Invisible Religion," 244.

${ }^{4}$ Szpakowska, "Nightmares", 23.

${ }^{5}$ For a study of the text; Hans Goedicke, Studies in the Instruction of King Amenemhet Ifor His Son (San Antonio, 1988). The propaganda aspect of the text has been examined by Carolyn Theriault, "The Instruction of Amenemhetas Propaganda," JARCE 30 (1993): 151-160.

${ }^{6}$ William Simpson, the Literature of Ancient Egypt: An Anthology of Stories, Instructions, Stelae, Autobiographies, and Poetry (Cairo: The American University in Cairo Press, 2003), 166.

${ }^{7}$ Miriam Lichtheim, Ancient Egyptian Literature 1 (London: University of California Press, 1973), 169184.

${ }^{8}$ Simpson, The Literature, 37; John Gee, Please Become an Angel: There Needs No Ghost, My Lord, Come from the Grave to Tell Us This, Dreams and Angels in Ancient Egypt (USA: Brigham Young University, 2004), 20-21
} 


\section{Freud's ${ }^{1}$ Theoretical Framework: He believes that dreams occur in two ways ${ }^{2}$ :}

- It may be returned to one of the instinctive repressed desires, and it stored in the subconscious because social conditions prevent them in reality. So, it takes its way during the sleep from the subconscious to the conscious, and it reveals itself as a dream.

- It may be a different desire from a waking life; some ideas that exist before conscious after it contains conflicting motives. It received support during sleep from one of the emotional elements. So the dreams may be emerge from the ego.

\section{Dreams in Ancient Egyptian Language:}

The word ' $k d d$ ' 'symbolized by a bed' by ancient Egyptians to denote 'sleep', word 'rsw. $t$ ' depicted as an open eye refer to 'dream', and 's $d r$ ' refers to 'lie down, go to bed, go to sleep, spend the night'. ${ }^{3}$

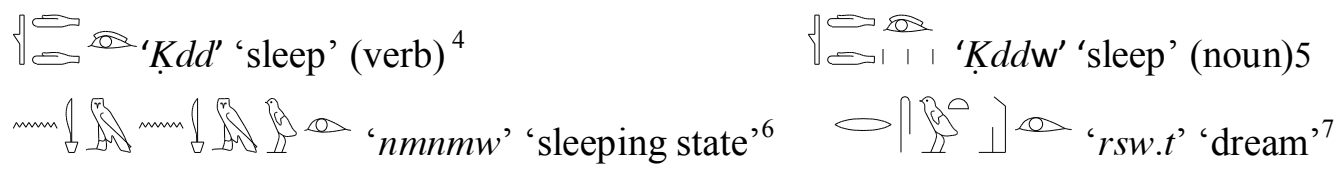

\footnotetext{
1 'Sigmund Freud (born Sigismund Schlomo Freud) May 6, 1856-September 23, 1939; was an Austrian neurologist and psychiatrist who co-founded the psychoanalytic school of psychology. Freud is known by his theories of the unconscious mind, especially involving the mechanism of repression; he presumed value of dreams as sources of insight into unconscious desires, he redefined the sexual desire as mobile and directed towards a wide variety of objects, also he had his therapeutic techniques, and understanding of transference in the therapeutic relationship. See, Sigmund Freud, Dream Psychology, Trans. M. D. Eder (USA: New York, 1920), 2.

${ }^{2}$ In Arabic; Gamila Meloky, “Altashkhees Alnafsy bi Taqniat Tahelel Alahlam li Aledwania wa Alkhouf Almarady wa Alsadma Alnafsia enda Almoraheq" (PhD diss., Wahran University, 2019), 72-76; Freud, Dream Psychology, 4-5.

3 'rsw.t' literally means 'awakening' and implies that the dreamer awakened in a different plain and was able to see those who dwelled there. The ancient Egyptians had no verb for dreaming, which suggests that they did not consider it an activity but rather a visual phenomenon. Whether the term ' $r s w . t$ ' or ' $k d . t$ ' was used, it was always used as a substantive and never a verb as usually in a context associated with verbs of visual perception, such as ' $m 33$ ' 'to see'. In Egyptian terms one did not 'do dreaming', it was not an action; one would 'see a dream', or 'see something in a dream'. It was thus perceived as an uncontrollable phenomenon external to the dreamer, and this is an important distinction to bear in mind; Dewsbury, "Invisible Religion," 244; Szpakowska, "Nightmares", 23.

${ }^{4} \mathrm{~Wb}$ II, 345.1 .

5 ' $k d . t$ ' is a substantive from the verb ' $k d$ ' 'to slumber'. The determinative of the word ' $k d$ ', one of the terms that more accurately express the action of dreaming or, more precisely, of having an oneiric vision or dream significantly, this word included an open eye decorated with makeup, which corroborates the idea of the dream as related to a state of awareness, of being associated with the ability to see, and even of being awake; Jose Serrano-Delgado, "The tekenu in Egyptian Funerary Ritual," Z̈̈S 138 (2011): 158; Szpakowska, Behind Closed Eyes, 16, 18; Szpakowska, "Nightmares", 23.
}

${ }^{6} \mathrm{~Wb}$ II, 268.1.

${ }^{7} \mathrm{~Wb}$ II, 452.1-4; 'rsw.t' was commonly used from the late Old Kingdom through the Coptic period, it is a substantive that finds its root in the word ' $r$ ' 'to awaken', they used the symbol of bed, and the symbol of open eye to express a dream. Accordingly that, the word dream gives another reading such as awaken within sleep, which is a description of the physiologic similarity of dreams to wakefulness, despite being asleep. See, Szpakowska, "Nightmares", 23; Tarek Asaad, "Sleep in Ancient Egypt," in Sleep Medicine, ed. Billiard. M. Chokroverty (USA: New York, 2015): 13; Gillis Lucy, And Now A word from Ancient Egypt: The Lucid Dream Exchange, http://www.dreaminglucid.com/issues/LDE50.pdf, 19. 206-2019. 
$\| \underline{y} r$ ' refers to 'lie down, go to bed, go to sleep, spend the night'. '

So dreams could be explicitly called 'good dreams' 'rsw.t nfr.t', while 'bad dreams' could be called 'rsw.t $\underline{d} w . t$ '.

\section{Concept of Dream and Nightmare:}

The dream was a phenomenon over which the dreamer had little control, and its permeable boundaries allowed both the divine and the demonic inhabitants of the beyond access to the visible world. ${ }^{3}$ In that sense, sleep was considered as a way to realize that mysterious world and the means to contact with gods and dead. So, the sleep and the death are the same in some aspects, in where the person is in a different world, being firm believers in the afterlife. ${ }^{4}$ That emphasized from its earliest appearance in Egyptian texts, where the dream seemed to have functioned as a link between the inhabitants of this world and the far world, a landscape inhabited by the gods, the justified dead. $^{5}$

Nightmare can be considered 'negative dream'. ${ }^{6}$ It enabled frightening or unwanted communication with the dead. In its oldest form, the nightmare is conceived of as an attack during sleep by a supernatural being, the entity responsible is often characterized as a hybrid being with animal extremities, such as teeth, claws, or horns. The nightmare is defined by the fear and terror which accompany this scenario of attack. It is thus a type of affect-laden dream: a dream carrying a strong, ego-shattering emotional charge. The other main classes of this kind of dream are the erotic dream and the ecstatic dream-encounter with a god. The three may blur together. ${ }^{8}$

\footnotetext{
${ }^{1} \mathrm{~Wb}$ IV, 390. 9-392. 6; Allen James, Middle Egyptian: An Introduction to the Language and Culture of Hieroglyphs (Cambridge: Cambridge University Press, 2000), 158, 462, 469.

${ }^{2}$ Szpakowska, "Nightmares", 23; Dewsbury, "Invisible Religion,” 243-244; Szpakowska, Behind Closed Eyes, 123.

${ }^{3}$ Szpakowska, "Nightmares", 21, 23.

${ }^{4}$ So, there were some rituals related to sleep to resemble what is adopted in preparation for death. Closely related to this concept of the tomb as a dwelling is the idea that the deceased 'lived' there, or at the very least, the physical body 'slept' there; Asaad, "Sleep in Ancient Egypt", 13; Dewsbury, "Invisible Religion," 243; Barbara O'Neill, "Sleep and the Sleeping in Ancient Egypt," Magazine Articles on Egyptological, April 3, 2012, http://www.egyptological.com/2012/04/sleep-and-the-sleeping-inancientegypt-8146. 20-6-2019.

${ }^{5}$ Szpakowska, "Nightmares", 23.

${ }^{6}$ Other early references to dreams qualified as bad are found in the Middle Kingdom 'Execration Texts'. These consist of hieratic texts which were inscribed on bowls or on human figurines usually composed of clay, stone, or occasionally wood. They have been discovered in regions as diverse as 'Mirgissa' in the south and 'Sakkara' in the north. Their archaeological contexts are rarely in royal temple or funerary zones, but more often within the vicinity of military fortresses or within secular cemeteries suggesting that at least some were created privately; Robert Ritner, The Mechanics of Ancient Egyptian Magical Practice (Chicago: The Oriental Institute of the University of Chicago, 1993), 140-145; Georges Posener, "Les textes d'envoûtement de Mirgissa," Syria 43(1966): 277-287; Szpakowska, "Nightmares", 25.

${ }^{7}$ Dewsbury, "Invisible Religion," 243; Louise Milne, the Terrors of the Night; Charms against the Nightmare and the Mythology of Dreams (Edinburgh: School of Art, University of Edinburgh, 2017), 7980 .

${ }^{8}$ Milne, the Terrors, 79-80; Dewsbury, "Invisible Religion," 248.
} 
Freud argues the dream formation was involved two main contents; visible content and hidden content. The ideas of dream and the dream content are presented like two sides of the same topic and the same matter in two different languages. Or, more properly, the dream content seems like a meaning of ideas of dream into another expression. ${ }^{1}$

\section{Stimulation of Guilt and Desire:}

One of the functions of dreams in the daily life of ancient Egyptians is communicating with the dead to achieve personal hopes. Evidence for guilt and desire in this communication comes from the New Kingdom Dream Book ${ }^{2}$, in addition to the evidence which comes from letters to the dead such as:

\section{- Letter to A dead from the Late Old Kingdom:}

author of the letter 'Heni' 'a priest' writes to his dead father for help, first reminding his father of the fact that it is he 'Heni' who continues to provide offerings for his well-being in the beyond. It seems that 'Heni' is being bothered in a dream by his father's servant 'Seni' who is also dead. 'Heni' denies responsibility for the beating of the servant 'Seni' and requests from his father to prevent 'Seni' from watching him in his dreams as well. ${ }^{3}$ Unfortunately, we have no evidence as to whether Heni's plea was heard, and whether his father successfully prevented Seni from causing his son any more nightmares. ${ }^{4}$

\section{- Letter to A dead known as the Misplaced Stela:}

A husband named 'Merirtyfy' missed his deceased wife, which is called 'Nebtetef', and he asked her to appear before him in a dream. He says, 'Please become an 3h-spirit for me [before] my eyes so that I may see you and that you may fight on my behalf in a dream, , which means that Communication with the dead through dreams is able to demonstrate both the objective and subjective dimensions of religiosity. ${ }^{6}$ Also, it means that he had a strong belief in the power of the desire motivating to may play role in achieving his wish.

Assumed from these pervious examples, according to Freud's theory ${ }^{7}$, there were purely psychical sources of stimulation; there was a constant connection

\footnotetext{
${ }^{1}$ According to Freud's interpretation; "the ideas of dream are immediately understandable, as soon as we have learnt them. The dream-content seemed to be pictographic script, we have to read its characters according to their symbolic relation, after transposed these characters individually into the language of the ideas of dream." See, Sigmund Freud, the Interpretation of Dreams, trans. James Starchy (New York: A Member of the Perseus Books Group, 2010), 295-296.

${ }^{2}$ Dream books are texts which list images that might typically appear in dreams and what they signify for the dreamer usually but not always, a prophecy relating to their future. See, Juliette Harrisson, "Cultural Memory and Imagination; Dreams and Dreaming in the Roman Empire" (PhD diss., University of Birmingham, 2009), 126.

${ }^{3}$ It Discovered while excavating the tomb of an overseer of priests named 'Meru' in 'Nag ed-Deir'; The folded papyrus, dated tentatively to the tenth dynasty, was found in the courtyard of Meru's tomb, in a subsidiary burial of a relative, who would presumably have delivered the letter to the deceased 'Meru'. It is find spot is revealing in that the walls of the tomb actually depict the individuals who are mentioned in the letter; the tomb owner Meru, his son Heni, as well as his servant Seni; Szpakowska, "Nightmares", 24. ${ }^{4}$ Szpakowska, "Nightmares", 24.

${ }^{5}$ Gee, Please Become an Angel, 2; Dewsbury, "Invisible Religion," 243.

${ }^{6}$ Dewsbury, "Invisible Religion," 248.

${ }^{7}$ Freud, Dream Psychology, 4.
} 
between the dream and some detail of the dreamer's life during the waking state. This positively establishes a relation between sleeping states and waking states and disposes of the widely prevalent view that dreams are purely nonsensical phenomena coming from nowhere and leading nowhere. Where 'Heni' in what looks be a case of a guilty conscience in reality which came out of the unconscious into consciousness like a dream. Also the sexual desires play an enormous part in unconscious. Where 'Merirtyfy' missed his deceased wife 'Nebtetef' and need to see her in his dreams.

\section{The Divine Stimuli:}

They often claimed to have a dream in which the god spoke to them directly. ${ }^{1}$ Dreams were used to legitimate a king or ruler, as they could claim that their power and protection were given to them by a god. ${ }^{2}$ For examples:

- The first hymn inscribed on the front and back of a stela 'Wien Env. 8390' that was created by or on behalf of a craftsman from Thebes named 'Ipuy' who describes an event is as follows: when I saw the Lady of the Two Lands in a dream and my heart became joyful. Then I was refreshed with her food. It is clear that 'Ipuy' experienced direct contact with a deity in his dream, and while evidence for such an event is very scarce, it was clearly considered possible for ordinary individuals to communicate with a god in this way. ${ }^{3}$

- 'If a man sees himself in a dream seeing barley and emmer (given) to those yonder, good; it means his protection by his god'.

Freud's pointed out that there was in every dream the attempted or successful gratification of some wish, conscious or unconscious. ${ }^{5}$ So, it is a highly probable that every dream communicate them with their gods. It is a successful gratification of some wishes in their conscious or unconscious such giving the divine power and protection from gods, and it seems that during these dreams an individual was able to provoke a response from his $\operatorname{god}^{6}$, to the point where the gods through the dreams would demand some pious act. ${ }^{1}$

\footnotetext{
${ }^{1}$ Harrisson, "Cultural Memory," 269.

2 The first fully recorded and preserved royal dream dates from the end of the fifteenth century B.C. 'Thutmose IV?' It is followed by another solitary example, the dream of the Pharaoh 'Merenptah' 'thirteenth century B.C?' Then from the latest period we have a group of reports concerning Egyptian kings from a variety of sources: one experienced by the Ethiopian 'Tanutamon' 'seventh century B.C?', one recorded by Herodotus, concerning a king called 'Sethos' supposed to have ruled at the time of the Assyrian invasion, and one mentioned by Plutarch of Ptolemy I; Leo Oppenheim, The Interpretation of Dreams in the Ancient Near East. With a Translation of an Assyrian Dream-Book (Philadelphia: The American Philosophical Society, 1956), 187.

${ }^{3}$ Dewsbury, "Invisible Religion," 281-282.

${ }^{4}$ Dream Book as clear evidence that during the New Kingdom an individual other than the king could see a god in a dream: for example If a man sees himself in a dream seeing a god who is higher, good; it means great sustenance; Dewsbury, "Invisible Religion," 248, 279.

${ }^{5}$ Freud, Dream Psychology, 4.

${ }^{6}$ Asaad, "Sleep in Ancient Egypt", 14. Voice oracles of gods as opposed to the new kingdom and third intermediate period oracles that gave their decision by the movement of the divine image are not clearly attested before the Greco-Roman era (332BC-AD395). Uncertainty in dating the advent of auditory oracles is created by difficulties interpreting texts that refer to the voice of god being heard or to the god 'speaking' both of which could actually refer to the report given by the priest who oversaw the oracle rather than pronouncement of the oracle itself, such claims can also refer to someone 'hearing' the voice
} 


\section{Internal (Organic) Somatic Stimuli:}

Dreams in ancient Egypt may be a warning (perhaps about illness) ${ }^{2}$, or sometimes considered as possible indicators of the dreamer's general state of health, or as diagnostic tools when the dreamer was ill. So, many medical opinions on the usefulness of dreams varied considerably. ${ }^{3}$

So, dreams were used in three different approaches in ancient Egyptian Medicine ${ }^{4}$ :

- The first (the most common) considered it likely that dreams coming from within the body might reflect the physical state of the body.

- Secondly, it was the possibility that dreams sent from an external source might relate to bodily concerns.

- Thirdly, it was hoped by those who practiced ritual incubation that a god or divine being would provide them with medical assistance through a dream.

Freud's theory assumed the same idea after thousands of years; where the feeling of body changes and physical effects increases and more deeper during the sleep, and It is as quite possible that the beginnings of an illness might make themselves felt in dreams before anything could be noticed of it in waking life, owing to the magnifying effect produced upon impressions by dreams. Medical writers, too, who were certainly far from believing in the prophetic power of dreams, have not disputed their significance as a premonition of illness. ${ }^{5}$

So, since it was believed that dreams in ancient Egypt were could serve as oracles, maybe contained messages from the gods, or answers delivered by the gods to help people with their daily questions and problems ${ }^{6}$, in sickness, Egyptians would travel to a to sleep overnight on a special dream bed in temple or shrine, to call the dreams searching for comfort, divine advice, or recovery from their dreams, which called dream incubation. Wherefore, that dream or sleep temples built especially to recall such dreams. $^{7}$

It is worth mentioning that the Dream Incubation was practicing in Greece. There were dream oracles, which were regularly visited by patients in search of recovery. A sick man would enter the temple of Apollo or Aesculapius, would perform various ceremonies there, would be purified by lustration, massage and incense, and then, in a state of exaltation, would be stretched on the skin of a ram that had been sacrificed. He would then fall asleep and would dream of the remedies for his illness. These would be

of the gods during a dream. See, Rozenn Bailleui-Lesuer, Between Heaven and Earth, Birds in Ancient Egypt, OIM 35 (Chicago: Oriental Institute of the University of Chicago, 2012), 179.

${ }^{1}$ Asaad, "Sleep in Ancient Egypt", 14; Libby Pelham, "the History of Dreams in Ancient Cultures," Updated september 21, 2012, http://www. analysedreams.co.uk/DreamsInAncientCultures. 24-6-2019.

2 Asaad, "Sleep in Ancient Egypt", 14; Pelham, "the History of Dreams".

${ }^{3}$ Harrisson, "Cultural Memory," 90.

${ }^{4}$ Harrisson, "Cultural Memory," 90.

${ }^{5}$ Freud, the interpretation, 65.

${ }^{6}$ Pelham, "the History of Dreams"

${ }^{7}$ The temples were open to believers in the god of the temple, as long as they were assured to be pure, before entering the temple. The god's name was written on a piece of linen, then burned it in a lamp. Every dreamer read a special prayer to him or her. See, Asaad, "Sleep in Ancient Egypt", 14; Pelham, "the History of Dreams". 
revealed to him either in their natural form or in symbols and pictures which would afterward be interpreted by the priests. ${ }^{1}$

\section{Stimuli behind Interpretation Dreams:}

\section{- The Principle of Discovery the Truth:}

Freud proved that many of dream visions are symbolical, which causes us to consider them, as absurd and unintelligible; the universality of those symbols, however, makes them very transparent. ${ }^{2}$ It is the same principle followed by the Egyptians, as they often sought out dream interpretation to find the true, although it is not known certainly how much these interpretative guides were used in daily life. ${ }^{3}$ Dream interpretation allowed Egyptians to foresee and anticipate crisis situations, while knowledge of 'heka' allowed Egyptians to engage with misfortune actively, either by producing amulets as a means of protection or, in case these proved to be ineffective, by preparing drugs and performing healing rites. ${ }^{4}$

Some Egyptians used a dream book to list their dreams with their interpretations (e.g, the dream book of the King's Scribe 'Qenherkhepshef') which dates during the reign of 'Ramesses II' '1279 BC' 5 , it saves in British Museum with name 'P. Chester Beatty IIIrecto 1-11' 'EA. 10683'. It was published by Gardiner in 1935 (pl. 1). ${ }^{6}$

The so-called Dream Book is widely considered to be a tool for the interpretation of dreams, and it implies that during the New Kingdom a slightly more intimate and active form of communication with the deceased via dreams was possible, it can be seen as a manual for interpreting dreams and giving them meaning. ${ }^{7}$ There are just over 140 dreams that are classified as 'good' and approximately 90 that are classified as 'bad'. This section of the papyrus is followed by a spell of protection for the dreamer. Then comes a list, set out of dream interpretations for a group of people known as 'the

${ }^{1}$ Freud, the Interpretation, 65.

${ }^{2}$ Freud, Dream Psychology, 4.

${ }^{3}$ Pelham, "the History of Dreams"

${ }^{4}$ Jacco Dieleman, “Through a Glass Darkly: Magic, Dream and Prophecy in Ancient Egypt,” Aestimatio 5 (2008): 17.

${ }^{5}$ Asaad, "Sleep in Ancient Egypt", 14.

${ }^{6}$ Papyrus Chester Beatty III (Length: 39.5 centimetres, Width: 21.2 centimetres): Hieratic literary text written by Qenherkhepshef) originally formed part of the archive of Qenherkhopshef, a well-known scribe from Deir el-Medina, The papyrus is divided over four frames and contains a manual for interpreting dreams on the recto and literary texts on the verso. The dream book on the recto is written in a fine literary hand of an unknown scribe. On the verso, the famous scribe Qenherkhepshef's copied a poem about the 'Battle of Kadesh' which took place in the reign of Ramesses II (1279-1213 BC) and added a copy of a letter he had written to the vizier. His bold and highly cursive handwriting is instantly recognizable. The manuscript was later owned by his young wife's second husband Khaemnun, and then his son Amennakht, both of whom added their names to the recto in handwriting that is less neat than that of the original copyist of the Dream book, but much less cursive than Qenherkhepshef's (under column 10); Scott Noegel et al, "Word Play in the Ramesside Dream Manual," SAK 35 (2007): 193-212; Alan Gardiner, et al, Hieratic Papyri in the British Museum, 3rd series: Chester Beatty gift 1 (London: British Museum, 1935), 9-27, pls. 5-8a, 12-12a; On the Provenance, see Pieter Pestman, "Who Were the Owners, in the Comunity of Workmen of the Chester Beatty Papyri?]," in Gleanings from Deir el-Medïna, ed. R. J. Demarée and Jace. J. Janssen (Leiden: Nederlands Instituut voor het Nabije Oosten te Leiden, 1982), 155172.

${ }^{7}$ Dewsbury, "Invisible Religion," 245. 
followers of Seth', they described in the papyrus as a red-headed man who drinks to induce turmoil and who is known to women as a result of his sexual prowess. ${ }^{1}$

\section{- The Hidden Meaning Principle:}

Freud assumed that: 'every dream has a hidden meaning, those dreams are designed to change some other process of thought with it, and that we have only to undo the exchange correctly to arrive at this hidden meaning. ${ }^{2}$

One of the functions of ancient Egyptian dream book is to discover theses possible hidden meanings in ordinary dreams with no obvious special content and, because they need to apply to as many people as possible, the dreams in dream book may be expected to represent 'typical' dreams from the ancient Egyptian culture which they were written in. ${ }^{3}$

\section{- The Principle of Opposites:}

'Szpakowska' ${ }^{4}$ has summarized some of the main methods it uses; some interpretations are based on the principle of opposites 'for example, to see oneself dead means one will have long life', some on characteristics of the dreamed object 'figs were often used in medicine, so if someone dreams of figs, it means they are ill' and some on myths, satire or proverbs. ${ }^{5}$ Freud thought that there are masochistic impulses in the mind, which may be responsible for a reversal such as this. ${ }^{6}$

\section{A Few Examples of Auspicious Dreams ${ }^{7}$, from P. ChesterBeatty III $^{8}$ :}

$$
\text { r. 2.8... [hr] rdi.t n.f hmtj } m[\ldots] ; \text { nfr , ht }[k 3 j] . f \text { im.sn }
$$

... Giving him copper as [...]; good, [it means] something at which he will be exalted.

$$
\text { r. } 2.9 \text {... [hr ....]3 hmm.t.f } n \text { h3y; [nfr], hm } \underline{d} w . w t p w \text { iry.f }
$$

... [...] his woman to a married man; good, it means that the bad things related to him will retreat.

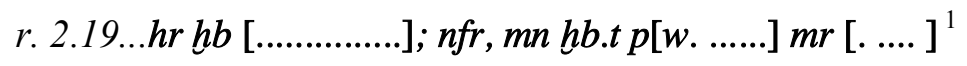

\footnotetext{
${ }^{1}$ Unfortunately, because so few dream interpretations for the followers of Seth remain, it is impossible to be certain why their dreams were given a separate section in the Dream Book. The inclusion of this section has led Gardiner to believe that the preceding section was for 'followers of Horus' who would probably have had characteristics considered more desirable in the Ramesside Period; Dewsbury, "Invisible Religion,” 246-247; Harrisson, “Cultural Memory,” 129-130.

${ }^{2}$ Interpreting a dream in Freud's theory implies assigning a 'meaning' to it that is, changing it by something which suits into our mental acts as a link having a validity and importance equal to the rest. See, Freud, the Interpretation, 121.

${ }^{3}$ The dreams in dream book are also (like incubation dreams) not confined to the top most section of the upper classes which means that anyone can read and use the dream book. See, Harrisson, "Cultural Memory," 126-127.

${ }_{5}^{4}$ Szpakowska, Behind Closed Eyes, 72.

${ }^{5}$ Harrisson, "Cultural Memory," 129-130.

${ }^{6}$ Freud, the Interpretation, 481.

7 'Qenherkhepesh's' dream book is divided into lists of auspicious and inauspicious dreams. Each interpretation begins with 'ir $m 33 s w s m r s w . t$ ' 'if a man sees himself in a dream', written vertically in columns. Horizontal rows consist of a protasis, then an evaluation of the dream image as ' $n f r$, good' or ' $\underline{d} w$, bad' followed by an apodosis; Noegel, et al, "Word Play”: 197.

${ }^{8}$ See, Gardiner, et al, Hieratic papyri, 3rd series 11-16, pls. 5-6; Noegel et al, "Word Play": 197-201.
} 
The Motivating Drives behind Dreams and Nightmares in ancient Egypt According to Freud's Theory

... Reducing(?) [ .........]; good, it means reducing [ .... . .] desire(?) [ . . ]

$$
\text { r. 2.21 ... hr wnm jwf nj } \quad \text { 3.t; } n f r, \text { s } 3 . f p w
$$

... Consuming the flesh of a donkey; good, it means that he will become great.

$$
\text { r. } 2.23 \text {... hr nh3.t rwd.tj; nfr, nhy.f pw } m[\text {...... ] }
$$

... Upon a sycamore tree which is flourishing; good, it means that he will lose [.....

].

$$
\text { r. } 3.1 \ldots h r h[\ldots . . .] \xi ; \text {; } n f r, g s 3 n . f w 3 . i p w
$$

... [.... ] a pond(?); good, it means that the road will be partial towards him.

$$
\text { r. 3.2 ... M33.f } g(3) s ; n f r, \text { e3. w nj ht.f }
$$

... While he sees mourning; good, (it means) the multiplying of his possessions.

\section{A Few Examples of Inauspicious Dreams from P. ChesterBeatty III $^{2}$ :}

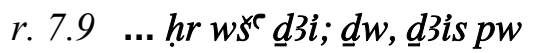

Chewing a djai-plant; bad, it means a debate.

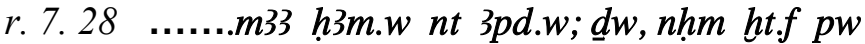

While seeing the catching of birds; bad, it means that something of his will be carried off.

\section{r. 8.4... hrr rdi.t n.fbn.t; $\underline{d} w$, ht pw bin.f hry.s.t}

Giving a harp to him; bad, it means something through which he might come to harm.

$$
\text { r. 8. } 12 \text {... ibh.w.f. hr hryry; } \underline{d} w \text {, mt si pw ni hry.w.f }
$$

When his teeth are falling out under him; bad, (it means that) one of his underlings will die.

\section{r. 8. $17 \ldots h r \underline{h} \underline{h} K \underline{h}$ '.t.f $\underline{h r} . t ; \underline{d} w, p r r . w p w$}

Shaving his lower body; bad, it means mourning.

$$
\text { r. 8. 26. . h hr rdi.t sntr }[h r] ~ h t ~ n n t r ; \underline{d} w, b 3 w \text { [ni] ntrr r.f }
$$

Placing incense on the flame for god; bad, it means that the power of god will be against him.

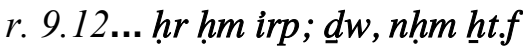

Pressing wine; bad, it means that his possession(s) will be confiscated.

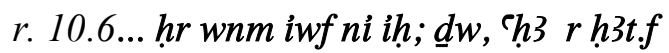

Eating the flesh of a cow; bad, it means that fighting is ahead of him.

\footnotetext{
${ }^{1}$ Although the determinative is missing for the word $h b$ in the protasis, Gardiner suggests reconstructing $h b . t$, reducing. Other possibilities include hhbi, dancing, hhb3, ravaging, and hhbs, hack up; Noegel et al, "Word Play": 198; Gardiner, et al, Hieratic papyri, 3rd series, 12 n. 2.

${ }^{2}$ Gardiner, et al, Hieratic papyri, 3rd series, 16-19, pls. 6-8; Noegel et al, "Word Play": 193-212; Asaad, "Sleep in Ancient Egypt”, 15; Dewsbury, "Invisible Religion,” 358; O’Neill, 'Sleep and the Sleeping'.
} 
There were other methods for interpretation where few people would have had access to such previous texts 'dream book'; few people were able to read it by themselves. There was a priest in many villages or a local scribe to interpret dreams. In addition to the wise woman which appeared in the texts of Deir el Medina. ${ }^{1}$

\section{Handling the Mysterious Emotions of Nightmares in ancient Egypt:}

As the motivating forces behind dreams can be an emotion, including guilt (Heni's Letter $)^{2}$, desire, needing the power, the protection, provoke a response, warning, etc. These motivations are accompanied by the inability to move, unpleasant visions, and intense fright.

They are somehow associated with the bad things and the deep-rooted iniquities or ailments, which were created by Seth, who associated with chaos and disorder. 'Oppenheim, explains that: 'evil dreams remain anonymous; their individual manifest content remains hidden behind the 'grammatical' plural in which they are consistently referred to in Akkadian, Hebrew and Egyptian' 'Ritner's suggests that these may have been perceived as potential 'magical assaults' by hostile foreigners, which if true, suggests that a living individual could actually cause others to see bad dreams. Indeed, evidence from the Late New Kingdom to the early Third Intermediate Period may provide evidence for this very control. ${ }^{6}$

Early and comprehensive protection was thus to repel the demon with a representation of itself. ${ }^{7}$ Prophylactic weapons agents of chaos may have been apotropaic bedposts, inlaid headboards, and headrests; it seems that headrests were valued possessions that functioned in life and in death. ${ }^{8}$

Although the inscriptions on these artifacts do not refer directly to dreams or nightmares, rather to the closely related state of sleep that may have afforded Egyptian sleepers protection from nightmares ${ }^{9}$, where their amuletic protection would have functioned magically as one slept. ${ }^{10}$

These ancient Egyptian Headrests, bedposts, and the related inlaid decoration of headboards were sometimes chiseled in the form of the dwarf god 'Bes', 'Beset', 'Sobek' and 'Tawaret, gods and goddesses' most often associated with women, children and the vulnerable sick, often brandishing knives and writhing snakes, these deities

\footnotetext{
${ }^{1}$ O'Neill,'Sleep and the Sleeping'. Such seers were consulted also on other issues affecting daily life including concerns over failing crops, or disputes with neighbors. The divination was also used to foresee misfortune, such as using her as a legal instrument to legitimize political decisions with a label of divine consent, or to expose someones's past misconduct, and his criminal behavior. Dieleman, "Through a Glass Darkly": 17.

${ }^{2}$ Szpakowska, "Nightmares", 24 no. 10; Bert States, Seeing in the Dark: Reflections on Dreams and Dreaming (London: Yale University Press, 1997), 235-250.

${ }^{3}$ Szpakowska, "Nightmares", 30.

${ }^{4}$ Oppenheim, the Interpretation, 231.

${ }^{5}$ Ritner, the Mechanics, 140.

${ }^{6}$ Szpakowska, "Nightmares", 25.

${ }^{7}$ Milne, The Terrors, 86.

${ }^{8}$ O'Neill, "Sleep and the Sleeping".

${ }^{9}$ Szpakowska, "Nightmares", 35-36.

${ }^{10}$ O'Neill,"Sleep and the Sleeping”.
} 
provided ritually charged protection against a multitude of threats. ${ }^{1}$ For example, the goddess 'Neith' herself make a rare appearance as the guardian of sleep on a headrest from the 'Saite Period', which depicts her shooting her arrows at an enemy who had presumably intended to bother the sleeper. ${ }^{2}$

The god 'Bes' who was particularly popular in households, played a vital role protecting the inhabitants of the house, particularly women and children, from a wide assortment of enemies and conditions ranging from childbirth and childhood diseases to unwelcome nocturnal visits. Then, at the end 'Bes' himself acquired a firm reputation as a god of dreams in the Ptolemaic Period. ${ }^{3}$

The dream book is also including many spells ${ }^{4}$ 'Chester Beatty III, sheet 3, recto, columns 8-11' His funerary headrest depicts the grotesque dwarf-god 'Bes', waving snakes to fend off dreams, , with the text: 'The scribe of Thoth and of Ma'at who love him, "Qenherkhepshef' 'son of 'Panakhte' justified. Spell for a good sleep in the land of 'Amen' by the royal scribe 'Qenherkhepshef' justified, a good sleep inside the western district for the justified. Made by the royal scribe 'Qenherkhepshef' justified $^{6}$ (pls, 2-4).

Also ancient Egyptians used 'Sleep medicine' for avoiding bad dreams and agents of chaos, where other textual sources reflect an association of nightmares with diseases and ailments; the earliest known treatment specifically designed to was found during an excavation of a tomb in a storehouse behind the 'Ramesseum' western Thebes from twelfth Dynasty. ${ }^{7}$ More detailed instructions concerning the prevention of nightmares can found in an Eighteenth Dynasty medical papyrus nestled amongst other spells against excessive female bleeding and miscarriages is a spell that includes an injunction to prevent a woman from seeing dreams. ${ }^{8}$

\footnotetext{
${ }^{1}$ Other composite creatures appeared alongside magical texts on headrests recovered from Middle Kingdom 'Lahun', the Twelfth Dynasty pyramid town and from New Kingdom 'Deir el Medina'; the latter home to the craftsmen of the Royal Tombs in the Valley of the Kings. These fearsome beings were harmless to innocent sleepers and regarded as potent protection against bad dreams and ill-intended nocturnal spirits, intent on creating havoc for the living; O'Neill, "Sleep and the Sleeping".

2 Georges Daressy, "Neith protectrice du sommeil," ASAE 10 (1910): 177-179; Szpakowska, "Nightmares", 39.

3 Georges Michaeilidis, "Bès aux divers aspects," BIE 45 (1963-1964): 53-93; Franz Ballod, Prolegomena zur Geschichte der zwerghaften Gotter in Agypten (Moskau: Buchdruckerei von H. Liessner und D. Sobko, 1913), 24-26; James Romano, "Notes on the Historiography and History of the Bes-Image in Ancient Egypt," BACE 9 (1998): 89-105; Szpakowska, "Nightmares", 36.

${ }^{4}$ Another spell to ward off nightmares can be found in 'P. Leiden I 348 v. 2', the text introduces itself literally as 'the book of driving out terrors which come in order to descend upon a man in the night'; Joris Borghouts, The Magical Texts of Papyrus Leyde I 348, OMRO 51 (Leiden: E. J. Brill, 1970), 32-33, 176186; Szpakowska, "Nightmares", 30-31.

${ }^{5}$ Milne, The Terrors, 86. In the case of the Chester Beatty spell, it is these ailments 'tms.w' and evil things ' $\underline{d} w$. $w t$ ' which must be driven out of the dreamer in order to treat his condition successfully, Szpakowska, "Nightmares", 29.

${ }^{6}$ Whether this scribe had made his own headrest is not known. The term 'justified' referred exclusively to someone already deceased. Practicalities (and perhaps, superstition) may indicate that Qenherkhepesh's son, or a close male relative would have completed the inscription on the scribe's behalf; O'Neill, "Sleep and the Sleeping".

${ }^{7}$ Szpakowska, "Nightmares", 26; Asaad, "Sleep in Ancient Egypt", 13, 17.

${ }^{8}$ Now in the British Museum as EA 10059, commonly known as the London Medical Papyrus 40 (13.914) in Hermann Grapow, Die medizinischen Texte in hieroglyphischer Umschreibung autographiert
} 
In addition to use fire and fire-breathing cobras for protect the living, whether king or commoner, from any dead or demons who attempted to gain access and terrify the living who are asleep, in a state that is halfway between life and death, however certain types of the clay cobras could represent surviving examples of ones that were used by the Egyptians to protect themselves from nightmares by placing a cobra in each corner of the room that contained a sleeper; a sacred space was created within the confines of which the vulnerable individuals would be guarded from hostile nocturnal entities. ${ }^{1}$

\section{Conclusion:}

Freud's theory assumed the same idea of dreams in ancient Egypt after thousands of years. The dream experience seemed to be something strange integrated between two sections of life which are totally continuous and consistent with each other. There were motivating drives behind all of these types of Dreams and nightmares, which based on linking dreams to unconscious psychological life. It may be returned to one of the instinctive repressed desires, which stored in the subconscious, it takes its way during the sleep from the subconscious to the conscious, and it reveals itself as a dream. Or it may be a different desire from a waking life; some ideas that exist before conscious after it contains conflicting motives. It received support during sleeping from one of the emotional elements.

(Berlin: Akademie-Verlag, 1958), 482-483; Wolfhart Westendorf, "Beiträge aus und zu den medizinischen Texten," ZAS 92 (1966): 145. This discussion follows the updated translation and commentary of Incantation 28 in Christian Leitz, Magical and Medical Papyri of the New Kingdom (London: British Museum Press, 1999), 69.

${ }^{1}$ Szpakowska, "Nightmares", 34-35. 


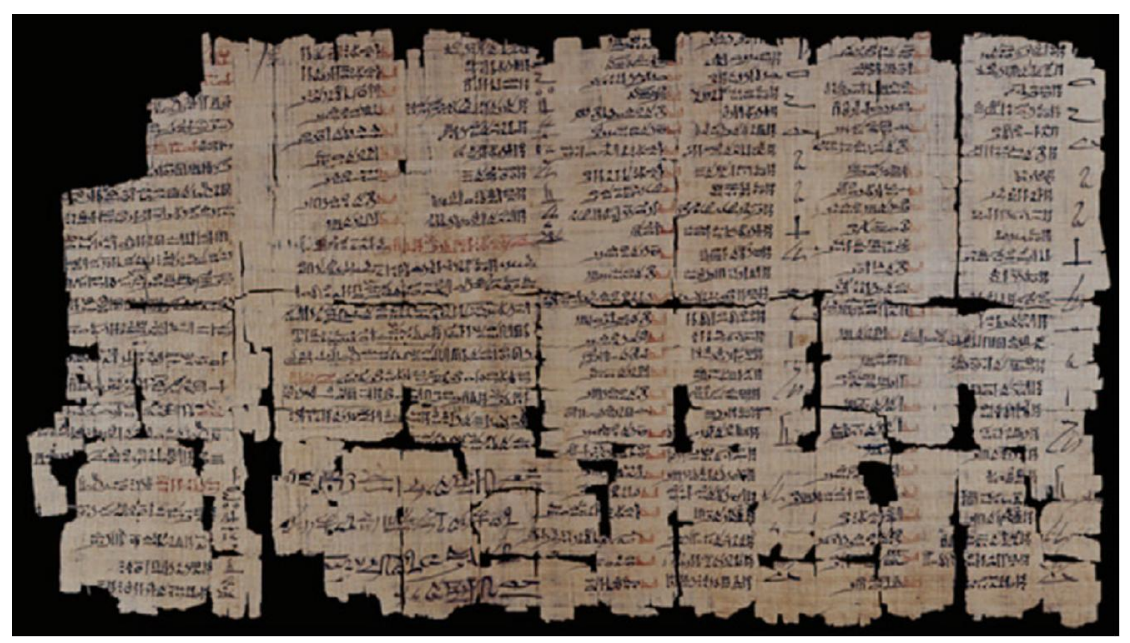

(pl. 1) Qenherkhepshef's Dream Book (P. Chester Beatty III) EA10683, 4. ${ }^{1}$

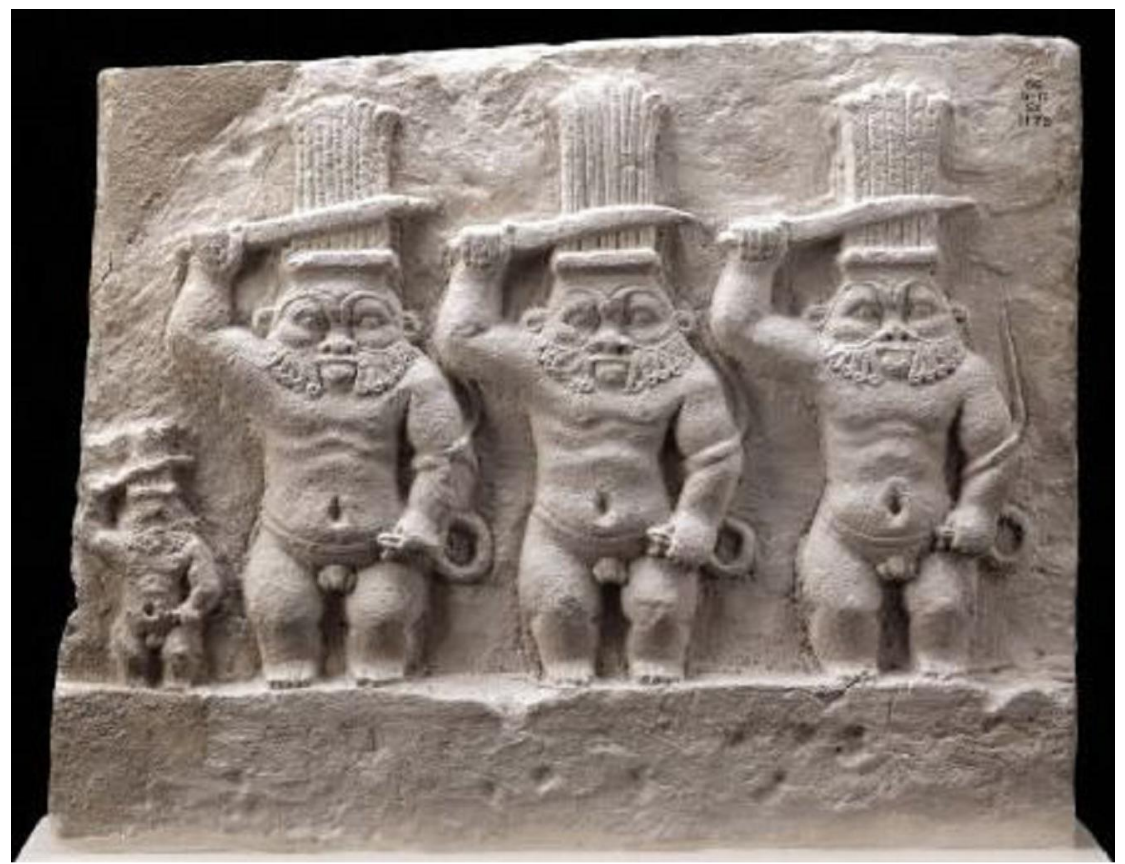

(pl. 2) Headrest of Qeniherkhepeshef, carved with protective figures of Bes, 1225 BC, 19th Dynasty, Deir el-Medina, Egypt. Limestone, 18.8 x 23 x 9.7cm. British Museum, London. Museum number: EA6378. ${ }^{2}$

\footnotetext{
${ }^{1}$ Photo: The Trustees of the British Museum, http://www.britishmuseum.org.

${ }^{2}$ Photo: The Trustees of the British Museum, http://www.britishmuseum.org.
} 

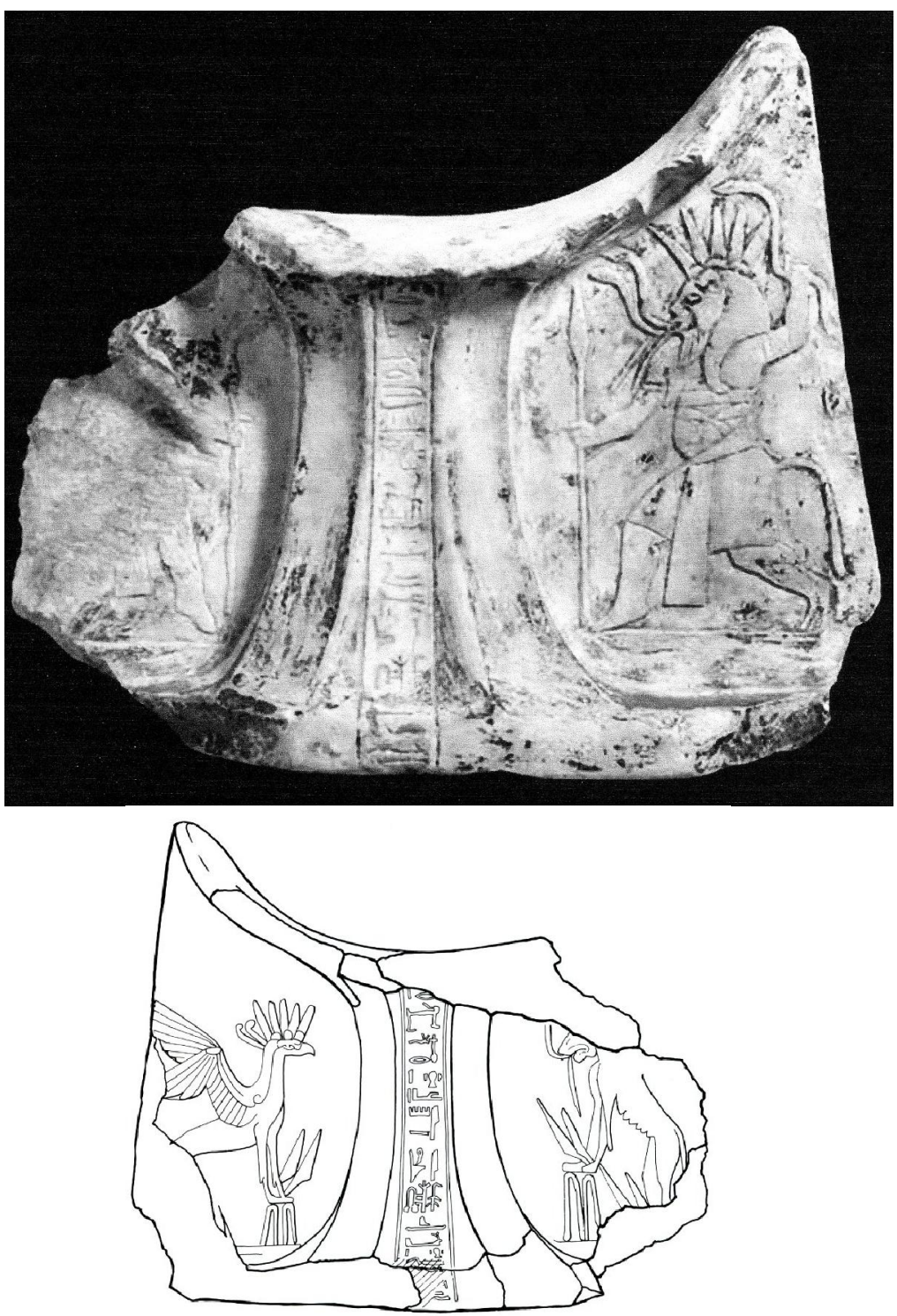

(pl. 3, 4) Mythical Creatures, Headrest of Qenherkhepesh, Nineteenth Dynasty.

British Museum, London. Museum number: EA63783. Photo: The Trustees of the British Museum. ${ }^{1}$

\footnotetext{
${ }^{1}$ Photo: The Trustees of the British Museum. http://www.britishmuseum.org.
} Facsimile; O’Neill, "Sleep and the Sleeping”, fig. 9. 


\section{Abbreviations}

- ASAE: Annales du Service des Antiquités de l'Égypte (Le Caire).

- BACE: Bulletin of the Australian Centre for Egyptology. Macquarie Univ. (Sydney)

- BIE: Bulletin de l'Institut égyptien, puis Bulletin de l'Institut d'Égypte (Le Caire)

- JARCE: Journal of the American Research Center in Egypt (Boston, New York)

-OMRO: Oudheidkundige Mededelingen vit het Rijksmuseum van Oudheden (Leyde)

- $S A K$ : Studien zur altägyptischen Kultur (Hambourg)

- Wb: Erman (A.), Grapow (H.), Wörterbuch der ägyptischen Sprache, 1926-1963 (Leipzig, Berlin)

-ZÄS: Zeitschrift für ägyptische Sprache und Altertumskunde (Leipzig, Berlin).

\section{Bibliography:}

- Asaad, Tarek. "Sleep in Ancient Egypt," in Sleep Medicine, edited by Billiard. M. Chokroverty. USA: New York, 2015.

- Bailleui-Lesuer, Rozenn, Between Heaven and Earth, Birds in Ancient Egypt, OIM 35. Chicago: Oriental Institute of the University of Chicago, 2013.

- Ballod, Franz. Prolegomena zur Geschichte der zwerghaften Gotter in Agypten. Moskau: Buchdruckerei von H. Liessner und D. Sobko, 1913.

- Borghouts, Joris. The magical Texts of Papyrus Leyden I 348. OMRO 51. Leiden: E. J. Brill, 1971.

-Daressy, Georges. "Neith protectrice du sommeil," ASAE 10 (1910): 177-179.

-Dieleman, Jacco. "Through a Glass Darkly: Magic, Dream and Prophecy in Ancient Egypt," Aestimatio 5 (2008): 16-22.

- Freud, Sigmund, Dream Psychology. Translated by M. D. Eder. USA: New York, 1920.

-............... The interpretation of Dreams, trans. James Starchy. New York: Member of the Perseus Books Group, 2010.

- Gardiner, Alan, et al, Hieratic Papyri in the British Museum, 3rd series: Chester Beatty Gift 1. London: British Museum, 1935.

- Gee, John. Please Become an Angel: There Needs No Ghost, My Lord, Come from the Grave to Tell Us This, Dreams and Angels in Ancient Egypt. Brigham Young University, 2004.

- Goedicke, Hans. Studies in the Instruction of King Amenemhet I for His Son. San Antonio, 1988.

- Grapow, Hermann. Die medizinischen Texte in hieroglyphischer Umschreibung autographiert. Berlin: Akademie-Verlag, 1958.

- James, Allen. Middle Egyptian: An Introduction to the Language and Culture of Hieroglyphs. Cambridge: Cambridge University Press, 2000.

- Leitz, Christian. Magical and Medical Papyri of the New Kingdom. London: British Museum Press, 1999.

- Lichtheim, Miriam. Ancient Egyptian Literature 1. London: University of California Press, 1973. 
- Michaeilidis, Georges. "Bès aux divers aspects," BIE 45 (1963-1964) : 53-93.

- Milne, Louise. The Terrors of the Night; Charms against the Nightmare and the Mythology of Dreams. Edinburgh: School of Art, University of Edinburgh, 2017.

- Møller-Olsen, Astrid. "Sharing a Dream: The Lucid Dreamscapes of Jorge Luis Borges and Can Xue," International Conference 'Exploring the China Dream' at Stockholm University (2015): 1-22.

- Noegel, Scott. "On Puns and Divination: Egyptian Dream Exegesis from a Comparative Perspective," in Through a Glass Darkly: Magic, Dreams, and Prophecy in Ancient Egypt. Edited by Kasia Szpakowska. Swansea: Classic Press of Wales, 2006.

- Noegel, Scott. et al, "Word Play in the Ramesside Dream Manual," SAK 35 (2007): 193-212.

- Oppenheim, Leo. The interpretation of Dreams in the Ancient Near East; With a Translation of an Assyrian Dream-Book. Philadelphia: The American Philosophical Society, 1956.

- Pestman, Pieter. "Who Were the Owners, in the Comunity of Workmen of the Chester Beatty Papyri?," in Gleanings from Deir el-Medïna. Edited by R. J. Demarée and J. J. Janssen. Leiden: Nederlands Instituut voor het Nabije Oosten te Leiden, 1982.

- Posener, Georges. "Les textes d'envoûtement de Mirgissa," Syria 43(1966): 277287.

- Ritner, Robert. The mechanics of Ancient Egyptian Magical Practice. Chicago: The Oriental Institute of the University of Chicago, 1993.

- Romano, James. "Notes on the Historiography and History of the Bes- Image in Ancient Egypt," BACE 9 (1998): 89-105.

- Serrano-Delgado, Jose. "The tekenu in Egyptian Funerary Ritual," Z̈̈S 138 (2011): 150-162.

- Simpson, William. The literature of Ancient Egypt: An Anthology of Stories, Instructions, Stelae, Autobiographies, and Poetry. Cairo: The American University in Cairo Press, 2003.

- States, Bert. Seeing in the Dark: Reflections on Dreams and Dreaming. London: Yale University Press, 1997.

- Szpakowska, Kasia. Behind Closed Eyes: Dreams and Nightmares in Ancient Egypt. Swansea: The Classical Press of Wales, 2003.

-............... , "Nightmares in Ancient Egypt," in Le cauchemar dans l'Antiquité: Actes des journées d'étude de l'UMR 7044 (15-16 Novembre 2007, Strasbourg), ed. Jean-Marie Husser and Alice Mouton. Paris: de Boccard, 2010, 21-39.

- Theriault, Carolyn. "The Instruction of Amenemhet as Propaganda," JARCE 30 (1993): 151-160.

-Westendorf, Wolfhart. "Beiträge aus und zu den medizinischen Texten," ZAS 92 (1966): 128-164.

\section{Dissertations:}

-Dewsbury, Laura. Invisible Religion in Ancient Egypt: A study into the Individual Religiosity of Non-royal and Non-elite Ancient Egyptians ( $\mathrm{PhD}$ diss., University of Birmingham, 2016). 
- Gamila Meloky, "Altashkhees Alnafsy bi Taqniat Tahelel Alahlam li Aledwania wa Alkhouf Almarady wa Alsadma Alnafsia enda Almoraheq" (PhD diss., Wahran University, 2019).

- Harrisson, Juliette. Cultural Memory and Imagination; Dreams and Dreaming in the Roman Empire (PhD. diss., University of Birmingham, 2009).

\section{Electronic Articles and Websites:}

- Lucy, Gillis. "And Now A word from Ancient Egypt: The Lucid Dream Exchange," http://www.dreaminglucid.com/issues/LDE50.pdf, 19.

- O’Neill, Barbara. "Sleep and the Sleeping in Ancient Egypt," Magazine Articles on Egyptological, April 3, 2012. http://www.egyptological.com/2012/04/sleep-and-thesleeping-in-ancientegypt-8146.

- http://www.britishmuseum.org. 